\title{
Compulsory divided property - problems and solutions within modernisation of Latvian legal system
}

\author{
Jolanta Dinsberga \\ Rīga Stradiņš University, Riga, Latvia
}

\begin{abstract}
After the end of the Soviet regime, a dual situation - a divided property with land and buildings owned by different persons - occurred in Latvia. Study objective: to describe key tendencies of modernising the Latvian legal system for discontinuation of compulsory divided property by examining historical development and legal framework thereof. Methods used: general scientific - descriptive, analytical, formally dogmatic, graphic; Legal interpretation methods - grammatical, systemic, teleological, historical. Conclusions: occurrence of the divided property is related to historical circumstances and causes various issues between building owners and landowners; thus, elaboration and adoption of new draft laws will ensure discontinuation of the divided property and well-balanced interests of the parties. The study could be binding to those willing to know more about legal system development tendencies in other country, i.e., in Latvia.
\end{abstract}

Key words: restriction, compulsory divided property, Land Reform.

\section{Introduction}

The right to property is one of the fundamental human rights guaranteed by Section 105 of the Constitution of the Republic of Latvia [1] and Convention for the Protection of Human Rights and Fundamental Freedoms [2]. According to Section 927 of the Civil Law (hereinafter the CL) of the Republic of Latvia (hereinafter - the RL) [3], an owner has full right of control over property. However, absolute power can be limited based on Section 928 of the CL [3]. The property rights can be restricted due to various reasons. Considering the topical problems in Latvia, the author will focus on issues between a building (construction) owner and landowner within legal relations of compulsory divided property (hereinafter - divided property).

The objective of the research: to describe the key tendencies of modernising the Latvian legal system for discontinuation of divided property by examining historical development and legal framework thereof.

Tasks: 1) to explain a concept of divided property, describe types thereof; 2) to characterise peculiarities of divided property in the late $19^{\text {th }}$ and early $20^{\text {th }}$ century; 3 ) to analyse occurrence of divided property in Latvia after 4 May 1990; 4) to analyse improvement of laws regarding regulation of divided property within modernisation of the Latvian legal system.

Having assessed legal and political processes in the country (see Clauses 2, 4.2 and 4.3 of the research), the author can assert that one of the most topical problems in the 
property rights area is related exactly to existence and abolition of divided property rights. For example:

1) Owners' usage of property is limited.

2) Building owners are forced to engage in compulsory lease relations and pay rent for the land beneath the building. The rent amount is determined through mutual agreement, or in case of disagreement - the amount of $6 \%$ of the land's cadastral value in towns and cities [4] and 5\% - in rural areas [5]. In the author's opinion, inadmissible inequality can be observed in determining the rent charge in identical factual situation for people in rural and urban areas.

3) Part of building owners refuse to pay rent and landowners have to turn to the court, which is time-consuming and costly.

4) Functionally necessary land plot $^{1}$ can be set either too big or too small, which affects the rent amount or limits management possibilities.

5) Laws do not stipulate that the owners must agree on maintenance of the land plot. This can be addressed by binding regulations of local governments, yet the solutions can differ. In one case, land maintenance is the responsibility of the building owner [6] while in the other - of the landowner [7].

6) When the owners want to abolish divided property, they do not always reach an agreement on a redemption price. In 2008, Research on Necessity for Modernisation of the Property Law Part of the CL was elaborated, and it states: "[..] it is necessary to introduce new institutes that would replace the existing system of divided property[..], using provisions of the Estonian and Lithuanian property laws as example." [8]. Divided property can be voluntary and compulsory. In this research, the author does not address the matters of voluntarily established divided property, yet it is important to note that overall issues of divided property are addressed by "Amendment to the CL" [10] of 19 March 2015.

Regarding compulsory divided property, on order of the Ministry of Justice (hereinafter MoJ), a large research - "On regulation of real property rights after completion of the Land Reform - issue of full introduction of CL's concept of inseparability of land and buildings" [11] was conducted. Based on this research, the MoJ started developing legislative means.

To understand peculiarities of the Latvian legal situation and the necessity for modernisation and process of implementing thereof, divided property is described both from historical and present-day viewpoint. Inquiry of historical conditions is the method that allows understanding depth of the problem, while analysis of present-day conditions allows finding the most effective solutions.

\section{Research materials}

Within the research, laws and regulations have been analysed (both historical and currently effective). The key studies reviewed are: research (2008) "On necessity for modernisation of the Property Law part of the CL and in relation to abolition of divided property", which reveals the faults in the CL regarding practical application and "On regulation of real property rights after completion of the Land Reform - issue of full introduction of CL's concept of inseparability of land and buildings" [12]. A relevant reflection of the Land Reform's historical development is given in the book of the civil rights specialist Joksts "Land Reform in Latvia and its Legal Security (1990-2005) [13].

\footnotetext{
${ }^{1}$ Functionally necessary land plot - the land necessary for house management [9].
} 


\section{Methods}

General scientific: descriptive method - by researching the regulatory framework of divided property, summarising and explaining information, as well as identifying problems. Analytical method - by researching laws and regulations, case law, opinions of authors with a view to clarify the problems of divided property. Induction and deduction - by stating separate opinions. Formally dogmatic - by critically assessing effective and draft provisions of regulatory framework of divided property and proposing solutions for their further formation. Graphic method - arrangement of information in a table was used for better perception.

Interpretation of legal provisions: grammatical - by studying the meaning and essence, from grammatical point of view, of concepts such as compulsory and voluntary divided property, Land Reform, compulsory lease. Historical method was used by researching legal provisions during the certain time of history. Systemic method - by studying peculiarities of formation of divided property in the passed laws and regulations about Land Reform in connection with the principle of land and building integrity comprised by the CL. Teleological - by reviewing the legislator's will when passing the laws and regulations granting public authorities the right to restore or allot property against payment; to understand its social objective.

\section{Results and discussion}

\subsection{Concept and types of divided property}

The concept of divided property is not new in Latvian and European law. "The construction of divided property provided that a property (land) can be owned by several persons in different subordination levels. For that reason, it was classed as superior property (dominum direktum) and inferior property (dominum utile)" [14].

Prior to passing the CL 1937, there were three types of divided property in Latvia: quitrent (obroks), hereditary lease and cinšs [payment of tax in cash - translator's note]. However, there were also other types in agreement forms such as "lifetime rent agreement for 99 years" and "building agreement" [15].

During the Land Reform, commenced in 1990, upon restoration of property rights for the former owners or their heirs or upon transfer of state or municipal properties for privatisation, an atypical situation formed - land and buildings ended up being owned by different persons. In legal doctrine, it is called divided property legal relations or compulsory lease legal relations, which contradict the principle of land and building integrity regulated in Section 968 of the CL, as well as cause legal and moral inconvenience for the owners.

Unlike voluntarily created divided property legal relations, in case of divided property, the owners of land and building (construction) are in mutually undesirable legal relations and often come into conflicts because the relations have originated due to historical circumstances rather than their own will.

Statistical data show that in Latvia there are in total 206,600 buildings, except engineering structures, that are situated on 68,900 land units owned by other persons [16], which is a considerable number, thus, affecting a major part of real property owners in Latvia.

\subsection{Compulsory divided property in the late $19^{\text {th }}$ and early $20^{\text {th }}$ century}

Studying the rights and historical development of Latvia it must be noted that they developed in complicated circumstances and under different regimes. However, there was constant work performed in Latvia to develop and improve the foundation of Latvian national civil rights. 
A united civil rights system in Latvia can be spoken about only after 1937 when passing the CL on 28 January. Until then, "the civil rights codified in 1832 in the tsarist Russia were still in force in Latgale [...]. In turn, the CL of prof. Frīdrihs Georgs fon Bunge of 1864 or Part III of the Baltic Local Law-book (BLLB) was applicable to the remaining territory of Latvia [..] [17].

Section 943 of BLLB also specified grounds for establishing divided property, i.e., either a law or a private order. Although the causes of divided property and the current compulsory lease relations are different, that does not change the idea of divided property: the superior owner keeps rights to the merits of the case.

With the CL being passed, attempts to give up the institute of divided property started. This aspect was especially emphasized in relation to the CL coming into force, stating that "one of the most important novelties in the property law part in the new CL after all is discarding of the so-called "divided property"" [18]. On 15 December 1938, the Law on Annulment of Divided Property Rights became effective (hereinafter - the Law 1938) [19]. "Giving up the institute of rights that gave preference to the privileged, mostly non-Latvian society sectors, was one step towards modernisation and simplification of civil rights with a view to eliminate social particulars in the territory of the new RL" [20]. It should be added that unlike the historical purpose of annulling divided property, at present the emphasis cannot be put on the privileged position of owners, since their rights are rather limited.

Section 2 of the Law 1938 allows concluding that divided property was annulled as the law became effective, since "[... in the morning of the day when the law comes into force, the users with property rights wake up as full owners [..]" [21]. Users of property rights were not required to take special actions for transferring the property rights. The Law 1938 stated that they had to pay a single redemption price to the superior owners (with exceptions). On 26 January 1939, the Minister for Justice Apsits issued Instructions to the Law on Annulment of Divided Property Rights [22] providing a detailed procedure of implementing redemption, bringing clarity of the actions to be taken in each stage and the rights and obligations of the involved entities. The present-day situation is similar, as there is a draft law addressing abolition of divided property.

Latvia gradually headed towards aligning the civil rights system, yet, on 17 June 1940, Soviet occupation started and "forced the Latvian Soviet Socialist Republic "joining" USSR" [23]. It affected development of the Latvian legal system. Therefore, the author gives an insight into rebirth and development of the Latvian legal system after independence restoration.

\subsection{Origination of compulsory divided property after 4 May 1990}

Latvian independence was restored on 4 May 1990.The Supreme Council of the Latvian SSR concluded that [..] the RL still de jure exists as a subject of international law and decided "[..] to announce the declaration "On Latvia joining the Union of Soviet Socialist Republics" passed on 21 July 1940 by the Latvian Saeima as null and void from the moment of passing" [24].

After independence restoration, one of the main goals was implementation of the Land Reform, development of a land policy. In the author's viewpoint, the concept "land policy" comprised almost all aspects related to rational usage of land in Latvia. Yet the priorities were restoration of a judicial state, restoration of property rights of the former owners and their heirs.

Already on 13 June 1990, the Supreme Council of the RL adopted a resolution "On Agrarian Reform in the RL" [25], which prescribed that the government must implement 
Table 1. Laws and regulations passed during implementation of the Land Reform [by author].

\begin{tabular}{|l|c|c|}
\hline \multicolumn{1}{|c|}{ Title of law } & $\begin{array}{c}\text { Date of } \\
\text { passing }\end{array}$ & $\begin{array}{c}\text { Number of } \\
\text { amendments }\end{array}$ \\
\hline $\begin{array}{l}\text { Resolution of the Supreme Council of the RL } \\
\text { "On Agrarian Reform in the RL" [26] }\end{array}$ & 13.06 .1990$. & \\
\hline On Land Commissions [27] & 10.07 .1990$. & 15 \\
\hline $\begin{array}{l}\text { Resolution of the LR SC on the procedure of the law of the RL } \\
\text { "On Land Use and Land Survey" coming into force" [28] }\end{array}$ & $\begin{array}{c}21.06 .1991 . \\
\text { Ineffective }\end{array}$ & \\
\hline On Land Use and Land Survey [29] & 21.06 .1991$. & 6 \\
\hline On Returning Building Properties to the Rightful Owners [30] & 30.10 .1991$. & 5 \\
\hline On the Denationalisation of Building Properties in the RL [31] & 30.10 .1991$. & 7 \\
\hline On Land Reform in the Rural Areas of the RL [32] & 21.11 .1990$. & 11 \\
\hline On Land Reform in the Urban Areas of the RL [33] & 20.11 .1991 & 33 \\
\hline $\begin{array}{l}\text { On the Time of Entry into Force and Application Procedure } \\
\text { of the Introduction, Parts of Inheritance Rights and Property Law } \\
\text { of the Renewed CL of the RL 1937 [34] }\end{array}$ & 07.07 .1992$. & 10 \\
\hline On Land Privatisation in Rural Areas [35] & & \\
\hline Land Register Law [36] & 09.07 .1992$. & 24 \\
\hline On Privatisation of State and Municipal Property Objects [37] & 22.12 .1937$. & 27 \\
\hline $\begin{array}{l}\text { On State and Municipal Land Property Rights and } \\
\text { Their Registration with Land Registers [38] }\end{array}$ & $\begin{array}{l}29.03 .1994 . \\
29.03 .1995 .\end{array}$ & 23 \\
\hline $\begin{array}{l}\text { On Privatisation of State and Municipal } \\
\text { Residential Houses [39] }\end{array}$ & 21.06 .1995$. & 22 \\
\hline On the Completion of Land Reform in Rural Areas [40] & 30.10 .1997$. & 14 \\
\hline On the Completion of Land Reform in Urban Areas [41] & 29.10 .1998$. & 8 \\
\hline $\begin{array}{l}\text { Resolution of the Council of Ministers No. 322 } \\
\text { On Regulation on Land in Rural Areas [42] }\end{array}$ & 25.11 .1991$. & \\
\hline
\end{tabular}

the Land Reform, the economic relations reform and the agrarian sector governance reform. It also included a procedure and time limits for granting land for usage or as property.

Several laws were passed for implementation of the Land Reform. Thus, formation of divided property must also be addressed. Property rights to land were restored to the previous owners or their heirs and they ended up owning also the land with buildings owned by other persons and built during the Soviet occupation. The most significant Land Reform laws are summarised in Table 1.

These laws are only a part of the documents passed during the Land Reform. The last column of the Table provides the number of amendments thereto. The author believes that frequent amending indicates that there are sudden changes due to globalisation. Nevertheless, the conclusion is that this is the reason why the legal framework development was incomplete /not thought out.

When analysing works by several authors (e.g., Joksts, Boruks) and intensity of the laws being passed, it can be concluded that the laws governing the Land Reform were passed in a big rush, influenced by different social and political factors, and therefore they repeatedly required amendments (from 1990 until 2002, 230 laws were passed) - negative consequences are still manifesting today. One of them is - derogations from the principle of land and building integrity, i.e., "a building built on land and tightly connected to it shall be recognised as a part of it" [43]. 
The legislator allowed restoring the property rights within historical boundaries also on the land plots with buildings owned by other persons, when passing the law "On the Time of Entry into Force and Application Procedure of the Introduction, Parts of Inheritance Rights and Property Law of the Renewed CL of the RL 1937" [44]. However, Section 14, Paragraph one of this law was amended on 10 January 1997, establishing that provisions of Sections 968 and 973 of the CL are not applicable and buildings or orchards (trees) shall be deemed as an independent property object if one of the five conditions mentioned in the appendix exists [45].

Comparing experience of Latvia and neighbouring Estonia, former owners and their heirs in Estonia could not regain the land, if there were buildings on it owned by the third parties. Such land remained as a state property. Building owners were able to use it and buy it out, while former owners or their heirs were granted land of equal worth without the buildings owned by other persons [46]. The author holds a view that the Estonian legislator has chosen a more successful solution compared to Latvia. However, at the same time, one cannot overlook various additional factors that urged the particular legal solution to be adopted in Latvia. "Development of the Land Reform and subsequently its enforcement was a difficult and complicated undertaking, as it needed to be done in circumstances where there was no political and ideological stability yet, heated discussions went on about which is the most acceptable the political and economic system for Latvia, about the significance and tasks of the state. [..] The peculiarity of the Land Reform in Latvia is that not only one united law or set of laws, consequent from each other in several stages, governed the reform. Instead, several laws were formed spontaneously with several sections that were changed repeatedly in the long process of discussing them until being passed by the LR SC (later - by Saeima), resulting in contradictions between separate laws, as well as within the scope of particular laws" [47].

Joksts finds that "[..] The task of the Land Reform legislation was to protect the rights of both the landowners and land managers. However, major disagreements were noticed already during the development of the legal basis of the reform, namely, there was no united viewpoint about the objectives and tasks of the land" [48]. Therefore, in the author's opinion, there is no reason to reproach developers of the regulatory basis because unity was in the fact that justice in property rights needs to be restored and the former owners and their heirs need to regain their properties.

At that time already, the former owners and their heirs were informed that divided property legal relations would form thereby. According to Section 12 of the law "On Land Reform in the Urban Areas of the RL" [49], upon restoring property rights of the former landowners and their legal heirs for land with structures owned by other persons, they were able to: 1) restore property rights to such land; 2) require land of equal worth; or 3) receive a compensation. The majority restored property rights within the historical boundaries. The author believes that it related to emotional factor, as it was important for people to regain their family properties. Numerous laws were also passed after Latvia regained independence and it was rather difficult for Latvian residents to know them well.

\subsection{Improvement of laws and regulations within modernisation of the Latvian legal system}

Active work is currently being done in Latvia on development of legislative means regarding compulsory lease legal relations and abolition of divided property: 1) the MoJ has developed a draft law on amendments to the law "On the Time of Entry into Force and Application Procedure of the Introduction, Parts of Inheritance Rights and Property Law of the Renewed CL of the RL 1937" (hereinafter - the Draft Law) [50]. In the author's opinion, a significant 
role in starting development of the Draft Law was played by judgements of the Constitutional Court on the laws regulating compulsory lease. For example, in judgement of 12 April 2018 in the case No. 2017-17-01 the Constitutional Court recognised that Section 1 of the law of 1 June 2017 "Amendments to the Law "On Privatisation of State and Municipal Residential Houses" and the law of 22 June 2017 "Amendments to the Law "On Land Reform in the Urban Areas of the RL"' do not correspond with Section 105 of the Constitution of the RL and are ineffective (in this case, the Constitutional Court assessed the rent payment volume set by the legislator) [51]. Judgements of the Constitutional Court No. 2008-36-01 [52] and No. 2010-22-01 [53] also need to be mentioned.

The Draft Law foresees substantial changes in regulation of compulsory lease legal relations. That might solve several problems related to this institute. From annotation of the Draft Law, it can be concluded that the current regulation of lease is expected to be replaced with lawful land usage rights against compensation, thereby preventing several problems caused by usage of the institute of lease to solve the situation of divided property [54].

As explained in the Draft Law, the lawful usage rights are a real servitude in favour of the construction, which is an independent property rights object. Such solution will simplify relations between the owners. In legal doctrine, the institute of compulsory lease has been compared to the institute of servitude for a long time [..] which explains why such regulation is included in the Draft Law. Other solutions offered by the Draft Law can be assessed positively. However, the author does not address them in more detail due to the limited volume of the research.

2) The MoJ has developed a draft law "Law on Abolition of Compulsory Divided Property Legal Relations in the Privatised Multi-Apartment Buildings" [55] (hereinafter - the Draft Law 2018). It is a modified model of abolishing divided property based on the criticised Draft Law 2015 [56] bearing the same title (its advancement was terminated), the author in an article [57] also made critical remarks thereon.

The Draft Law 2018 proposes a legal mechanism that applies to divided property between a landowner and owners of apartments in a privatised multi-apartment building. It does not apply to property divided between the state and municipality as the landowner and owners of apartments in a multi-apartment building [58].

The objective of the above law is - to discontinue divided property between such owners.

The key idea - divided property is discontinued by building owners exercising a special redemption right with substantial support of the state in carrying out all administrative actions (e.g., upon making changes in the Land Register Section, owners of divided property are freed from state and stamp duties. This can be evaluated positively, although Section 16, Paragraph 1 states that the state may provide support, which means that rendering of support, is the right, not an obligation).

The draft law also addresses issues as to determining the land to be redeemed and price thereof and protecting lawful interests of all parties.

In viewpoint of the MoJ, passing of the Draft Law would introduce legal measures that would allow resolving the problems of divided property on the merits - by abolishing it [59].

The Draft Law 2018 was passed by the Saeima in the $1^{\text {st }}$ reading on 19 April 2018[60] and is planned to become effective on 1 January 2021. 


\section{Conclusions}

1) Presence of divided property in Latvia relates to historical circumstances and numerous problems, which can be eliminated within the legal system modernisation - by passing new and amending current laws and regulations.

2) The legal system modernisation is a continuous process. The legislator cannot always arrange and promptly adapt the legal system to the rapid economic, social, technological, and political developments. However, it should be acknowledged that contribution to law development after independence restoration is huge.

The Draft Law "Law on Abolition of Compulsory Divided Property Legal Relations in the Privatised Multi-Apartment", compared to the wording of 2015, has been reshaped, is logically structured and does not contain the sharply criticised provisions. Upon passing the law, abolition of divided property and ensuring of the principle of land and building integrity will be successful. Yet, in case of failing to reach an agreement on discontinuing divided property the relations between the owners will possibly be made simpler and a balance between interests of the parties will be provided by passing the law "Amendments to the Law "On the Time of Entry into Force and Application Procedure of the Introduction, Parts of Inheritance Rights and Property Law of the Renewed CL of the RL 1937'”.'

\section{References}

[1] Latvijas Republikas Satversme (1922), Latvijas Vēstnesis 43 (1993)

[2] Cilvēktiesību un pamatbrīvību aizsardzības konvencija (1950), Pirmais protokols, Latvijas Vēstnesis 143/144 (858/859) (1997)

[3] Civillikums, ValdībasVēstnesis (hereinafter - LV) 44 (1937)

[4] Par zemes reform Latvijas Republikas pilsētās, 12. Panta pirmās dą̧as piezīme. Latvijas Republikas Augstākās Padomes un Valdības Ziņotājs (hereinafter -LVAPVZ) 49/50 (1991)

[5] Par zemes privatizāciju lauku apvidos, 6. Panta sestā daļa. LVAPVZ 32/33/34 (1992)

[6] Rīgas pilsētas teritorijas kopšanas un būvju uzturēšanas saistošie noteikumi: RD 2015. gada 28. Aprīla saistošo noteikumu Nr. 146, 3.2. punkts. LV 84(5402) (2015)

[7] Jelgavas pilsētas administratīvās teritorijas labiekārtošana un inženierbūvju uzturēšana: Jelgavas pilsētas domes 24.05.2012. saistošie noteikumi Nr. 12-15., LV, 109(4712) (2012)

[8] Pētījums par Civillikuma Lietu tiesību daļas (ceturtās, piektās, sestās un septītās nodaļas) modernizācijas nepieciešamību un attiecībā uz dalītā īpašuma izbeigšanu. Available: https://www.tm.gov.lv/files/archieve/lv_documents_petijumi_ cl_ceturta_piekta_sesta_un_septita_nodala.doc

[9] Dzīvojamo māju pārvaldīšanas likuma 1. pants, LV 96 (2009)

[10] Likums “Grozījums Civillikumā”, LV 56 (2015)

[11] Nekustamā īpašuma tiesību regulējums pēc zemes reformas pabeigšanas - Civillikuma zemes un ēku (būvju) nedalāmības koncepta pilnīgas ieviešanas problēma. Available: https://www.tm.gov.lv/files/archieve/lv_documents_petijumi_final_ report.re_land_reform_and_divided_property_concept.2008_12_12.lat. janisl.pdf

[12] Latvijas Republikas Tieslietu ministrija. PAR: nekustamā īpašuma tiesību regulējums pēc zemes reformas pabeigšanas - Civillikuma zemes un ēku nedalāmības koncepta pilnīgas ieviešanas problēma (2008). Available: https://www.tm.gov.lv/files/ archieve/lv_documents_petijumi_final_report.re_land_reform_and_ divided_property_concept.2008_12_12.lat.janisl.pdf 
[13] O. Joksts, Zemes reforma Latvijā un tās tiesiskais nodrošinājums (199.-2005) (Rīga, Multineo, 2006)

[14] F. Švarcs, Latvijas 1937. gada 28. Janvāra Civillikums un tā rašanās vēsture (Rīga, TNA, 2011)

[15] Vietējo civillikumu kopojums (Vietējo likumu kopojuma III. dalsa.) Tulkojums ar pārgrozījumiem un papildinājumiem, kas izdoti līdz 1927. g. 31. decembrim, un ar dažziem paskaidrojumiem. Tieslietu ministrijas sevisšksas komisijas sagatavojumā, 942. Pants (Rīga, Valters un Rapa, 1928)

[16] Likumprojekts. Grozījumi likumā "Par atjaunotā Latvijas Republikas 1937. Gada Civillikuma ievada, mantojuma tiesību un lietu tiesību daļas spēkā stāšanās laiku un piemērošanas kārtību". Available: https://www.tm.gov.lv/ lv/cits/pazinojums-par-lidzdalibas-iespejam-likumprojektagrozijumi-likuma-par-atjaunota-latvijas-republikas

[17] Latvijas tiesību vēsture 1914-2000. Mācību grāmata juridiskajām augstskolām un fakultātēm prof. dr.iur. Dītriha Andreja Lēbera redakcijā (Rīga, Fonds Latvijas vesture, 2000)

[18] Latvijas Republikas Satversmes tiesas (2011). gada 25.oktobra spriedums lietā Nr. 2011-01-01.14.3. 1.punkts. Available: http://www.satv.tiesa.gov.lv/ wp-content/uploads/2016/02/2011-01-01_Spriedums.pdf

[19] Likums par dalītā īpašuma tiesību atcelšanu, Valdības Vēstnesis 286 (1938)

[20] F. Švarcs, Latvijas 1937. gada 28. Janvāra Civillikums un tā rašanās vēsture (Rīga, TNA, 2011)

[21] H. Apsīts, Paskaidrojumi pie Likuma par dalītu īpašuma tiesību atcelšanu (Rīga, Valsts tipogrāfija, 1938)

[22] Instrukcija pie Likuma par dalītu īpašuma tiesību atcelšanu (1939), Valdības Vēstnesis 23 (1939)

[23] F. Švarcs, Latvijas 1937. gada 28. janvāra Civillikums un tā rašanās vēsture. (Rīga, TNA, 2011)

[24] LPSRAP deklarācija Par Latvijas Republikas neatkarības atjaunošanu, Ziņotājs 20 (1990)

[25] 13.06.1990. LR AP lēmums "Par agrāro reform Latvijas Republikā", LVAPVZ 29 (1990)

[26] 13.06.1990. LR AP lēmums "Par agrāro reform Latvijas Republikā", LVAPVZ 29 (1990)

[27] Par zemes komisijām, LVAPVZ 31 (1990)

[28] LR AP lēmums Par Latvijas Republikas likuma "Par zemes lietošanu un zemes ierīcību" spēkā stāšanās kārtību. Available: https://likumi.lv/doc. php?id=68669

[29] Par zemes lietošanu un zemes ierīcību, LVAPVZ 31/32 (1991)

[30] Par namīpašumu atdošanu likumīgajiem īpašniekiem, LVAPVZ 46 (1991)

[31] Par namīpašumu denacionalizāciju Latvijas Republikā, LVAPVZ 46 (1991)

[32] Par zemes reformu Latvijas Republikas lauku apvidos, LVAPVZ. Available: https://likumi.lv/doc.php?id=72849 49 (1990)

[33] Par zemes reformu Latvijas Republikas pilsētās, LVAPVZ, 49/50 (1991)

[34] Par atjaunotā Latvijas Republikas 1937.gada Civillikuma ievada, mantojuma tiesību un lietu tiesību daļas spēkā stāšanās laiku un piemērošanas kārtību, LVAPVZ 29/31 (1992)

[35] Par zemes privatizāciju lauku apvidos, LVAPVZ 32/33/34 (1992)

[36] Zemesgrāmatu likums (1937), LVAPVZ 16/17 (1993) 
[37] Par valsts un pašvaldību īpašuma objektu privatizāciju, LV 27 (1994)

[38] Par valsts un pašvaldību zemes īpašumatiesībām un to nostiprināšanu zemesgrāmatās, LV 56 (1995)

[39] Par valsts un pašvaldību dzīvojamo māju privatizāciju, LV 103 (1995)

[40] Par zemes reformas pabeigšanu lauku apvidos, LV 296/297 (1997)

[41] Par zemes reformas pabeigšanu pilsētās, LV 333 (1998)

[42] MP lēmums Nr.322 Par Nolikumu par lauku apvidu zemi (1991), LVAPVZ 10 (1992)

[43] A. Boruks Zemes izmantošana un kadastrs Latvijā (Rīga, LLU Skrīveru zinātnes centrs, VZD, 2001)

[44] Likums "Par atjaunotā Latvijas Republikas 1937.gada Civillikuma ievada, mantojuma tiesību un lietu tiesību daļas spēkā stāšanās laiku un piemērošanas kārtību", Ziņotājs 29 (1992)

[45] Ministru kabineta. gada 10. janvāra noteikumi Nr. 20 Grozījums likumā "Par atjaunotā Latvijas Republikas 1937. gada Civillikuma ievada, mantojuma tiesību un lietu tiesību dạ̧as spēkā stāšanās laiku un kārtību”, LV 12/13/14/15 (1997). Expired 21.05.1997

[46] Pētījums. Civillikuma zemes un ēku (būvju) nedalāmības koncepta piln̄̄gas ieviešanas problēma (2008). Available: https://webcache.googleusercontent. com/search?q=cache:_8cTGuUFDbEJ :https://www.tm.gov.lv/files/ archieve/lv_documents_petijumi_final_report.re_land_reform_and divided_property_concept.2008_12_12.lat.janisl.pdf+\&cd=1\&hl=lv\& $\mathrm{ct}=\mathrm{clnk} \& \mathrm{gl}=\mathrm{lv}$

[47] A. Boruks, Zemes Izmantošana un Kadastrs Latvijā (Rīga, LLU Skrīveru zinātnes centrs, VZD, 2001)

[48] O. Joksts, Zemesreforma Latvijā un Tās Tiesiskais Nodrošinājums (1990-2005) (Rīga, Multineo, 2006)

[49] Likums "Par zemes reformu Latvijas Republikas pilsētās", LVAPVZ 49/50 (1991)

[50] Likumprojekts. Grozījumi likumā "Par atjaunotā Latvijas Republikas (1937). Gada Civillikuma ievada, mantojuma tiesību un lietu tiesību daļas spēkā stāšanās laiku un piemērošanas kārtību". Available: https://www.tm.gov.lv/lv/cits/ pazinojums-par-lidzdalibas-iespejam-likumprojektagrozijumi-likuma-par-atjaunota-latvijas-republikas

[51] Satversmes tiesas 12.04.2018. spriedums Nr. 2017-17-01. Available: http:// www.satv.tiesa.gov. $1 \mathrm{v}$

[52] Satversmes tiesas 15.04.2009. spriedums Nr. 2008-36-01. Available: http:// www.satv.tiesa.gov. $1 \mathrm{v}$

[53] Satversmes tiesas 27.01.2011. spriedums Nr. 2010-22-01. Available: http:// www.satv.tiesa.gov.lv

[54] Likumprojekts. Grozijumi likumā "Par atjaunotā Latvijas Republikas 1937. Gada Civillikuma ievada, mantojuma tiesību un lietu tiesību daļas spēkā stāšanās laiku un piemērošanas kārtību" (2019). Available: https://www.tm.gov.lv/ lv/cits/pazinojums-par-lidzdalibas-iespejam-likumprojektagrozijumi-likuma-par-atjaunota-latvijas-republikas

[55] Likumprojekts "Piespiedu dalītā īpašuma privatizētajās daudzdzīvokļu mājās izbeigšanas likums". Available: http://titania.saeima.lv/LIVS12/saeimal ivs12.nsf/webSasaiste?OpenView\&restricttocategory=1211/Lp12 (2018)

[56] Likumprojekts "Piespiedu dalītā īpašuma tiesisko attiecību privatizētajās daudzdzīvokḷu mājās izbeigšanas likums”. Anotācijas 2.3. punkts. (2015). Available: http://titania.saeima.lv/LIVS12/saeimalivs12.nsf/0/ CD1A6440A69EB8BAC2257ED1003CBA2C?OpenDocument\#b 
[57] J. Dinsberga, I. Tiesniece, Problems Related to the Abolition of Divided Real Estate. Ownership, EKA 13(2), 77-88 (2016). Available: https://content.sciendo.com/view/journals/jec/13/2/article-p77.xml

[58] Likumprojekta "Piespiedu dalītā īpašuma privatizētajās daudzdzīvokḷu mājās izbeigšanas likums" anotācija (2018). Available: http://titania.saeima. lv/LIVS12/saeimalivs12.nsf/0/5986C97B49BD24A3C225826D004B1314? OpenDocument\#a

[59] Latvijas Republikas TM (2018). Available: https://www.tm.gov.lv/lv/ aktualitates/tm-informacija-presei/likumprojektu-par-piespiedudalita-ipasuma-privatizetajas-daudzdzivoklu-majas-izbeigsanunodos-saeim

[60] Latvijas Republikas Saeima (2018). Available: http://titania.saeima.lv/ LIVS12/saeimalivs12.nsf/webSasaiste?OpenView\&restricttocategory= $1211 / \operatorname{Lp} 12$ 